\title{
Digestion times and predation potentials of Pelagia noctiluca eating fish larvae and copepods in the NW Mediterranean Sea
}

\author{
Jennifer E. Purcell ${ }^{1, *}$, Uxue Tilves ${ }^{2}$, Verónica L. Fuentes ${ }^{2}$, Giacomo Milisenda ${ }^{3}$, \\ Alejandro Olariaga ${ }^{2}$, Ana Sabatés ${ }^{2}$
}

${ }^{1}$ Western Washington University, Shannon Point Marine Center, 1900 Shannon Point Rd, Anacortes, WA 98221, USA

${ }^{2}$ Institut de Ciències del Mar, CSIC, P. Marítim 37-49, 08003 Barcelona, Spain

${ }^{3}$ Dipartimento di Scienze e Tecnologie Biologiche ed Ambientali, Università del Salento, 73100 Lecce, Italy

\begin{abstract}
Predation is the principal direct cause of mortality of fish eggs and larvae (ichthyoplankton). Pelagic cnidarians and ctenophores are consumers of ichthyoplankton and zooplankton foods of fish, yet few estimates exist of predation effects in situ. Microscopic analyses of the gastric 'gut' contents of gelatinous predators reveal the types and amounts of prey eaten and can be used with digestion time (DT) to estimate feeding rates (prey consumed predator ${ }^{-1}$ time $^{-1}$ ). We measured the DT and recognition time (RT) of prey for Pelagia noctiluca, an abundant jellyfish with increasing blooms in the Mediterranean Sea. DT of fish larvae averaged 2.5 to $3.0 \mathrm{~h}$ for $P$. noctiluca (4-110 mm diameter) and was significantly related to jellyfish and larval sizes. In contrast, DT of fish eggs ranged from 1.2 to $44.8 \mathrm{~h}$ for jellyfish $\leq 22 \mathrm{~mm}$ diameter ('ephyrae'), but DT was not significantly related to ephyra or egg diameter. Approximately half of the eggs ingested were not digested. DT of copepods averaged $4 \mathrm{~h}$. We also measured DT and RT of salps, euphausiids, and miscellaneous zooplankton. Temperature $\left(20-25^{\circ} \mathrm{C}\right)$ generally did not significantly affect DT of any prey. Estimated potential predation effects of ephyrae on fish larvae in the Catalan Sea in 1995 showed great variability among 9 stations $\left(0-3.7 \%\right.$ consumed $\left.\mathrm{h}^{-1}\right)$. We discuss how sampling methods contributed to variation in predation estimates and offer recommendations to improve accuracy. Our results enable estimation of predation on ichthyoplankton and competition for zooplankton prey, which can have extremely important effects on fish populations globally.
\end{abstract}

KEY WORDS: Anchovy $\cdot$ Jellyfish $\cdot$ Salp $\cdot$ Fish eggs $\cdot$ Ichthyoplankton $\cdot$ Zooplankton $\cdot$ Competition

\section{INTRODUCTION}

Much of fisheries research has been directed towards predicting annual recruitment of fish into a fishery. The Critical Period and Aberrant Drift hypotheses (Hjort 1914) inspired 20th-century recruitment fisheries oceanography research towards factors affecting the early life history of fish. The main factors believed to determine recruitment variability now include the interactions of temperature and other physical processes on prey availability and larval condition, which in turn determine their vul- nerability to predators (Houde 2008). 'It is now evident that high and variable predation is the principal, [proximate] agent of mortality' (Bailey \& Houde 1989, Houde 2008, p 63).

Many species of pelagic cnidarians and ctenophores eat fish eggs and larvae (ichthyoplankton) (reviewed by Purcell 1985, Purcell \& Arai 2001), yet studies on the magnitude of this predation remain rare. During the 1980s and 1990s, several studies quantified removal rates of ichthyoplankton by pelagic cnidarians and ctenophores in containers ranging in size from 25 to 63001 (reviewed by Purcell \& 
Arai 2001). The results of those studies were affected by being conducted in artificial conditions (Purcell \& Arai 2001). A second approach to estimate predation on ichthyoplankton by pelagic cnidarians and ctenophores is to collect the predators in situ, thereby preserving their natural prey without experimental interference. Calculation of ingestion rates (prey eaten predator $^{-1}$ time $^{-1}$ ) also requires estimation of the time prey can still be recognized in gut contents; calculation of predation effects (\% prey standing stock consumed time $\mathrm{e}^{-1}$ ) further requires information about the abundances of the predators and prey in situ.

Interest in gelatinous species has resurged recently, probably because of their increasing interference with human enterprises in coastal oceans (Purcell et al. 2007). One species of particular concern is the holoplanktonic species Pelagia noctiluca that has caused economic damage to aquaculture in northern Europe (Doyle et al. 2008, Raffaele 2013) and to tourism, fisheries, aquaculture, and energy industries in the Mediterranean (reviewed by Mariottini et al. 2008, Canepa et al. 2014). P. noctiluca has a long history of blooms in the Mediterranean Sea (Goy et al. 1989) that appear to be increasing in frequency and duration (Daly Yahia et al. 2010, Kogovšek et al. 2010, Licandro et al. 2010, Bernard et al. 2011).

$P$. noctiluca consumes a variety of prey, including copepods and other crustaceans, gelatinous zooplankton, pelagic mollusks, appendicularians, and fish eggs and larvae (Malej 1982, Vućtić 1982, Sabatés et al. 2010, Rosa et al. 2013). Copepods were the most numerous prey consumed by ephyrae in the NW Mediterranean Sea (Sabatés et al. 2010). Although fish larvae averaged $<1 \%$ of the available mesozooplankton, they ranged from 5 to $32 \%$ of the prey in ephyrae; anchovy Engraulis encrasicolus larvae were the most frequently consumed (Sabatés et al. 2010). Thus, $P$. noctiluca is potentially important as a predator of ichthyoplankton and as a competitor of fish larvae and zooplanktivorous fish. Those effects are pervasive but difficult to evaluate. Because predation effects on prey populations increase with pelagic cnidarian and ctenophore population sizes (Purcell \& Arai 2001, Purcell \& Decker 2005), ichthyoplankton will likely suffer greater mortality as populations of these predators increase.

The in situ feeding rates of $P$. noctiluca were not calculated from gut contents in previous studies due to a lack of data on the digestion times of the various prey types. During cruises of the FishJelly project in 2011 and 2012, we measured digestion length of time and the times prey could be recognized in the gastric pouches ('guts') of $P$. noctiluca medusae and ephyrae. We emphasized ichthyoplankton, but also included common zooplankton organisms. Our objective was to measure digestion times in order to use this information in combination with gut content data for P. noctiluca collected at comparable temperatures to calculate predator feeding rates and predation effects on comparable prey. As an example, we used the gut content data for $P$. noctiluca ephyrae from Sabatés et al. (2010) to estimate their potential predation on fish larvae and copepods off the Catalan coast (NW Mediterranean) in 1995.

\section{MATERIALS AND METHODS}

Digestion measurements of fish larvae, fish eggs, and zooplankton by Pelagia noctiluca medusae and ephyrae were made in the Catalan Sea during cruises on board the RV 'García del Cid' (17 June to 4 July 2011 and 13 to 21 July 2012). Sea near-surface temperature and salinity were estimated by the ship's system. Near-ambient seawater temperature ( $\mathrm{T}$ in ${ }^{\circ} \mathrm{C}$ ) was maintained in the ship's laboratory by means of near-surface water pumped into kreisels and water baths containing the experimental containers. Fish larvae, fish eggs, and zooplankton used for digestion measurements were selected under magnification of a dissecting microscope from plankton tows of a $60 \mathrm{~cm}$ diameter bongo net with $300 \mu \mathrm{m}$ mesh. Fish larvae were identified to the lowest taxon possible. Anchovy eggs were identified to species by their oval shape. Fish larva total length (TL), copepod cephalothorax length, and fish egg diameter were measured to the nearest $0.1 \mathrm{~mm}$ with calipers with the aid of a dissecting microscope immediately before they were fed to $P$. noctiluca. Body lengths of salps (excluding protrusions) and other large species were measured to the nearest $0.5 \mathrm{~mm}$. Fish larval length was converted to dry mass by regressions for the most similar taxa in Pepin (1995) and Rossi et al. (2006). Our methods, outlined below, were considered 'natural feeding' as defined by FitzGeorge-Balfour et al. (2013) and differed for medusae (observed visually while in kreisels) and ephyrae (observed with a dissecting microscope).

$P$. noctiluca medusae ( $>22 \mathrm{~mm}$ diameter) were collected at night from the surface with a long-handled dip net and placed immediately in a bucket with seawater. They were kept on board in 3001 kreisels with weakly flowing seawater, as illustrated by Purcell et al. (2013). A prey item held with forceps and touched to the oral arms was ingested quickly, and the ingestion time was recorded. After ingestion, the prey item 
was observed continuously to track its final location in the gastric pouch. Thereafter, each rapidly digesting or transparent prey (i.e. fish larva, salp) was checked visually at $\leq 15 \mathrm{~min}$ intervals and each slowly digesting, conspicuous prey (i.e. euphausiid) at $\leq 60 \mathrm{~min}$ intervals. Only large fish larvae, euphausiids, and salps were visible once ingested by the medusae; therefore, fish eggs and copepods were not tested on medusae because they could not been seen after ingestion. The length of time that prey could still be seen in the guts was recorded and designated 'recognition time' (RT). Prey that could no longer be seen were considered to be digested, and the time was recorded and designated 'digestion time' (DT). Egestion of the prey remains was occasionally observed (error $=0 \mathrm{~min})$. Otherwise, the error $(\%$ of DT) was calculated from one-half of the final observation interval. After digestion of 1 prey item, each medusa was fed another prey and the process was repeated. Medusae appeared to be healthy for 3 to $4 \mathrm{~d}$ in the kreisels and were not used for digestion estimates afterwards. The swimming bell diameter then was measured to the nearest $1 \mathrm{~cm}$ by placing the medusa subumbrella down on a ruler.

Because we could not determine whether fish larvae digested by medusae on the cruise would be recognized in gut content analysis, we conducted an experiment at the Institut de Ciències del Mar in Barcelona, Spain (Table 1). Medusae from laboratory culture were placed in $300 \mathrm{l}$ kreisels with weakly flowing ambient seawater and each was given 1 fish larva, as above. At 15 to 90 min intervals, 3 to 6 of the medusae were preserved in $5 \%$ formalin solution. Their gastric pouches were examined later with a dissecting microscope to determine whether the prey could be recognized as a fish larva. This experiment was conducted twice (18 and 25 July 2013) with 3 species of larvae: anchovy Engraulis encrasicolus (Engraulidae), round sardinella Sardinella aurita (Clupidae), and bullet tuna Auxis rochei (Scombri- dae) that had been collected during the previous night using a Bongo net $(60 \mathrm{~cm}$ diameter, 300 and $500 \mu \mathrm{m}$ meshes) from nearby coastal waters. These results were compared to the digestion observations made on board ship. Medusae in which the larvae could no longer be seen were also included in the analysis of digestion time.

$P$. noctiluca ephyrae and post-ephyrae with small oral arms and tentacles (hereafter, all referred to as 'ephyrae,' with a diameter $\leq 22 \mathrm{~mm}$ ) were collected in short surface hauls with a Neuston net $\left(1.5 \mathrm{~m}^{2}\right.$ mouth, $1 \mathrm{~mm}$ mesh). Undamaged ephyrae were kept individually in 25 to $350 \mathrm{ml}$ glass bowls or beakers in which they could swim freely, with container size increasing with specimen size. A fish egg, larva, or zooplankter held with forceps and put in contact with each ephyra was ingested quickly. This time of ingestion was recorded, and each ephyra was checked under magnification of a dissecting microscope at 5 to 60 min intervals, with prey requiring prolonged digestion (fish eggs) being checked at the longer intervals. DT, RT, and \% error were determined as described for medusae. Ephyral diameter was measured to the nearest $1 \mathrm{~mm}$ with calipers under a dissecting microscope. We used multiple linear regressions to test whether DT was related to T, P. noctiluca diameter, or prey size (largest dimension). Regressions were made only when sufficient data were available. When data did not meet assumptions of normality and constant variance, we used $\log _{10}$ transformation before statistical analysis. One-way ANOVA was used to test for differences in digestion times among fish larval taxa and among fish egg diameters. Digested and undigested eggs were tested for differences in ephyral sizes and egg sizes with $t$-tests. When those data failed to meet assumptions after transformation, we used a non-parametric $t$-test (Mann-Whitney rank sum test). All data were presented as mean $\pm \mathrm{SD}$.
Table 1. Numbers of single fish larvae recognizable in Pelagia noctiluca medusae following digestion and preservation at intervals of 15 to $90 \mathrm{~min}$. Results are shown as the number recognizable/number tested. Number of larvae digested $=$ number tested - number recognizable. ' 0 ' indicates that all larvae were completely digested. Temperature $=21.3^{\circ} \mathrm{C}$. Species were anchovy Engraulis encrasicolus, round sardinella Sardinella aurita, bullet tuna Auxis rochei. NT: not tested

\begin{tabular}{|lccccccc|}
\hline \multirow{2}{*}{ Species } & Larval & \multicolumn{4}{c}{ Time interval (min) } & \multicolumn{2}{c|}{ ( } \\
\cline { 3 - 7 } & length $(\mathrm{mm})$ & 15 & 30 & 45 & 60 & 90 \\
\hline Anchovy \& round sardinella & $7-9$ & $6 / 6$ & $6 / 6$ & $2 / 11$ & $0 / 9$ & NT \\
Bullet tuna & $9-11$ & NT & $3 / 3$ & $3 / 3$ & $3 / 3$ & $0 / 6$ \\
\hline
\end{tabular}

\section{RESULTS}

To test when larvae digested by medusae $(35.7 \pm 2.1 \mathrm{~mm}$ diameter $)$ could not be recognized as fish larvae with microscopic examination, we examined the gut contents of medusae preserved at intervals, as described above (Table 1). All larvae were easily recognizable after 15 and $30 \mathrm{~min}$. The long, thin anchovy and round sardinella larvae could not be 
recognized as fish larvae after 45 or $60 \mathrm{~min}$. The larger bullet tuna larvae could still be recognized in the gut contents after 45 or $60 \mathrm{~min}$, but not after $90 \mathrm{~min}$ of digestion. Based on these results, we removed digestion data for 5 anchovy larvae $>10 \mathrm{~mm}$ long that could not be seen within swimming medusae on board ship after 30 min.

DTs of Pelagia noctiluca medusae and ephyrae fed 1 fish larva averaged 2.5 to $3.0 \mathrm{~h}$ (Table 2). DTs of all medusae and ephyrae combined were significantly related to ephyral diameter (D) and larval length (L), but not to $\mathrm{T}\left(\mathrm{R}^{2}=0.258, F_{3,205}=24.23, \mathrm{p}<0.001\right.$; $\log _{10} \mathrm{D} t=-8.33 ; \mathrm{p}<0.001 ; \log _{10} \mathrm{~L} t=6.23 ; \mathrm{p}<0.001$; $\mathrm{T} t=0.66 ; \mathrm{p}=0.513 ; \log _{10} \mathrm{DT}=0.334+0.562 \times \log _{10} \mathrm{~L}$ $-0.620 \times \log _{10} \mathrm{D}$ ). DT of combined medusae and ephyrae increased with larval length and decreased with the diameter of P. noctiluca (Fig. 1). Because our methods differed for medusae ( $>22 \mathrm{~mm}$ diameter) and ephyrae $(\leq 22 \mathrm{~mm})$, we considered the 2 groups separately in further analyses.

DTs of both ephyrae and medusae were significantly related to diameter and larval length; DTs were shorter for smaller larvae and larger $P$. noctiluca. DTs for fish larvae were not significantly related to T. Similar results were obtained for a multiple regression using larval dry mass (DM) instead of length; however, the relationship with $\mathrm{DM}\left(\mathrm{R}^{2}=\right.$ $0.288, F_{3,102}=13.74, \mathrm{p}<0.001, \log _{10} \mathrm{DM} t=3.85 ; \mathrm{p}<$ 0.001 ) was not as strong as with length (Table 2). The DTs for ephyrae differed significantly $\left(F_{5,101}=346.36\right.$, $\mathrm{p}<0.001$ ) among different types of larvae (Table 3); pairwise comparisons of the DT of anchovy versus all

Table 2. Digestion time (DT) and recognition time (RT) for Pelagia noctiluca given single fish larvae, salps, and copepods unless noted otherwise. Errors (\% of DT) and multiple regression statistics are also given. Salps given to medusae were Salpa fusiformis; those given to ephyrae were Thalia democratica. Data are presented means $\pm \mathrm{SD}$, with ranges in parentheses. $\mathrm{T}$ : temperature; NS: not significant; NT: not tested

\begin{tabular}{|c|c|c|c|c|c|c|c|}
\hline $\begin{array}{l}- \text { Jellyfish }- \\
\text { Diameter (D, mm) }\end{array}$ & $\mathrm{n}$ & $\mathrm{T}\left({ }^{\circ} \mathrm{C}\right)$ & $\begin{array}{l}\text { Prey length } \\
\quad(\mathrm{L}, \mathrm{mm})\end{array}$ & DT (h) & $\begin{array}{c}\text { Error } \\
(\%)\end{array}$ & Regression statistics & $\mathrm{RT}(\mathrm{h})$ \\
\hline Medusae & & & Fish larvae & & & & \\
\hline $\begin{array}{l}48.6 \pm 20.6 \\
(25-110)\end{array}$ & 63 & $\begin{array}{c}22.7 \pm 1.3 \\
(20.2-25.5)\end{array}$ & $\begin{array}{c}14.1 \pm 6.5 \\
(5-30.0)\end{array}$ & $\begin{array}{l}2.1 \pm 2.2 \\
(0.8-8.3)\end{array}$ & $\begin{array}{c}13.3 \pm 12.5 \\
(0-50)\end{array}$ & $\begin{array}{l}\mathrm{R}^{2}=0.425 \\
F_{3,59}=14.55 ; \mathrm{p}<0.001 \\
\log _{10} \mathrm{D} t=-0.79 ; \mathrm{p}=0.432 \mathrm{NS} \\
\log _{10} \mathrm{~L} t=6.41 ; \mathrm{p}<0.001 \\
\mathrm{~T} t=-1.04 ; \mathrm{p}=0.300 \mathrm{NS} \\
\log _{10} \mathrm{DT}=0.024+1.061 \times \log _{10} \mathrm{~L}\end{array}$ & $\begin{array}{l}0.9 \pm 0.8 \\
(0.3-5.8)\end{array}$ \\
\hline Ephyrae & & & Fish larvae & & & & \\
\hline $\begin{array}{l}13.4 \pm 5.2 \\
(4-22)\end{array}$ & 107 & $\begin{array}{c}23.4 \pm 0.9 \\
(20.7-24.4)\end{array}$ & $\begin{array}{c}5.9 \pm 2.6 \\
(1.5-13.0)\end{array}$ & $\begin{array}{l}3.0 \pm 1.7 \\
(0.3-8.3)\end{array}$ & $\begin{array}{c}20.6 \pm 25.2 \\
(0-50)\end{array}$ & $\begin{array}{l}\mathrm{R}^{2}=0.319 \\
F_{3,103}=15.89 ; \mathrm{p}<0.001 \\
\log _{10} \mathrm{D} t=-2.73 ; \mathrm{p}=0.007 \\
\log _{10} \mathrm{~L} t=5.71 ; \mathrm{p}<0.001 \\
\mathrm{~T} t=-1.37 ; \mathrm{p}=0.172 \mathrm{NS} \\
\log _{10} \mathrm{DT}=1.213+0.662 \times \\
\quad \log _{10} \mathrm{~L}-0.379 \times \log _{10} \mathrm{D}\end{array}$ & $\begin{array}{l}1.2 \pm 0.2 \\
(0.2-5.8)\end{array}$ \\
\hline Medusae & & & Salps & & & & \\
\hline $\begin{array}{l}42.2 \pm 11.4 \\
(15-60)\end{array}$ & 30 & $\begin{array}{c}22.2 \pm 1.4 \\
(19.6-23.7)\end{array}$ & $\begin{array}{c}21.3 \pm 12.0 \\
(1.5-40.0)\end{array}$ & $\begin{array}{l}2.0 \pm 1.8 \\
(0.4-6.9)\end{array}$ & $\begin{array}{l}7.7 \pm 9.0 \\
(0-35)\end{array}$ & $\begin{array}{l}\mathrm{R}^{2}=0.766 \\
F_{3,103}=27.23 ; \mathrm{p}<0.001 \\
\mathrm{D} t=0.66 ; \mathrm{p}=0.515 \mathrm{NS} \\
\mathrm{L} t=4.26 ; \mathrm{p}<0.001 \\
\mathrm{~T} t=-2.87 ; \mathrm{p}=0.008 \\
\mathrm{DT}=12.217-0.519 \times \mathrm{T}+0.087 \times \mathrm{L}\end{array}$ & $\begin{array}{l}1.8 \pm 1.1 \\
(0.2-5.0) \\
L\end{array}$ \\
\hline Ephyrae & & & Salps & & & & \\
\hline $\begin{array}{l}10.4 \pm 0.6 \\
(10-11)\end{array}$ & 5 & $\begin{array}{c}23.4 \pm 1.3 \\
(21.6-25.2)\end{array}$ & $\begin{array}{c}5.6 \pm 2.6 \\
(4.0-10.0)\end{array}$ & $\begin{array}{l}3.2 \pm 2.1 \\
(1.0-5.7)\end{array}$ & $\begin{array}{l}16.2 \pm 8.8 \\
(5-29)\end{array}$ & NT & $\begin{array}{l}1.8 \pm 1.4 \\
(0.4-4.0)\end{array}$ \\
\hline Ephyrae & & & 1 copepod & & & & \\
\hline $\begin{array}{l}11.8 \pm 0.6 \\
(7-22)\end{array}$ & 51 & $\begin{array}{c}23.9 \pm 0.7 \\
(22.3-25.0)\end{array}$ & $\begin{array}{l}1.3 \pm 0.3 \\
(1.0-2.0)\end{array}$ & $\begin{array}{l}4.1 \pm 1.3 \\
(1.2-7.8)\end{array}$ & $\begin{array}{l}10.2 \pm 5.3 \\
(0-29)\end{array}$ & $\begin{array}{l}\mathrm{R}^{2}=0.131 \\
F_{3,44}=2.20 ; \mathrm{p}=0.101 \mathrm{NS} \\
\mathrm{D} t=-1.66 ; \mathrm{p}=0.105 \mathrm{NS} \\
\mathrm{L} t=1.20 ; \mathrm{p}=0.235 \mathrm{NS} \\
\mathrm{T} t=-1.10 ; \mathrm{p}=0.276 \mathrm{NS}\end{array}$ & $\begin{array}{l}2.2 \pm 1.2 \\
(0.7-5.0)\end{array}$ \\
\hline Ephyrae & & & 2-4 copepods & & & & \\
\hline $\begin{array}{l}17.0 \pm 3.6 \\
(13-20)\end{array}$ & 4 & 23 & 1.1 & $\begin{array}{l}4.1 \pm 0.5 \\
(3.4-4.7)\end{array}$ & $\begin{array}{l}11.4 \pm 5.2 \\
(7-20)\end{array}$ & NT & $\begin{array}{l}1.8 \pm 0.4 \\
(1.3-2.1)\end{array}$ \\
\hline
\end{tabular}



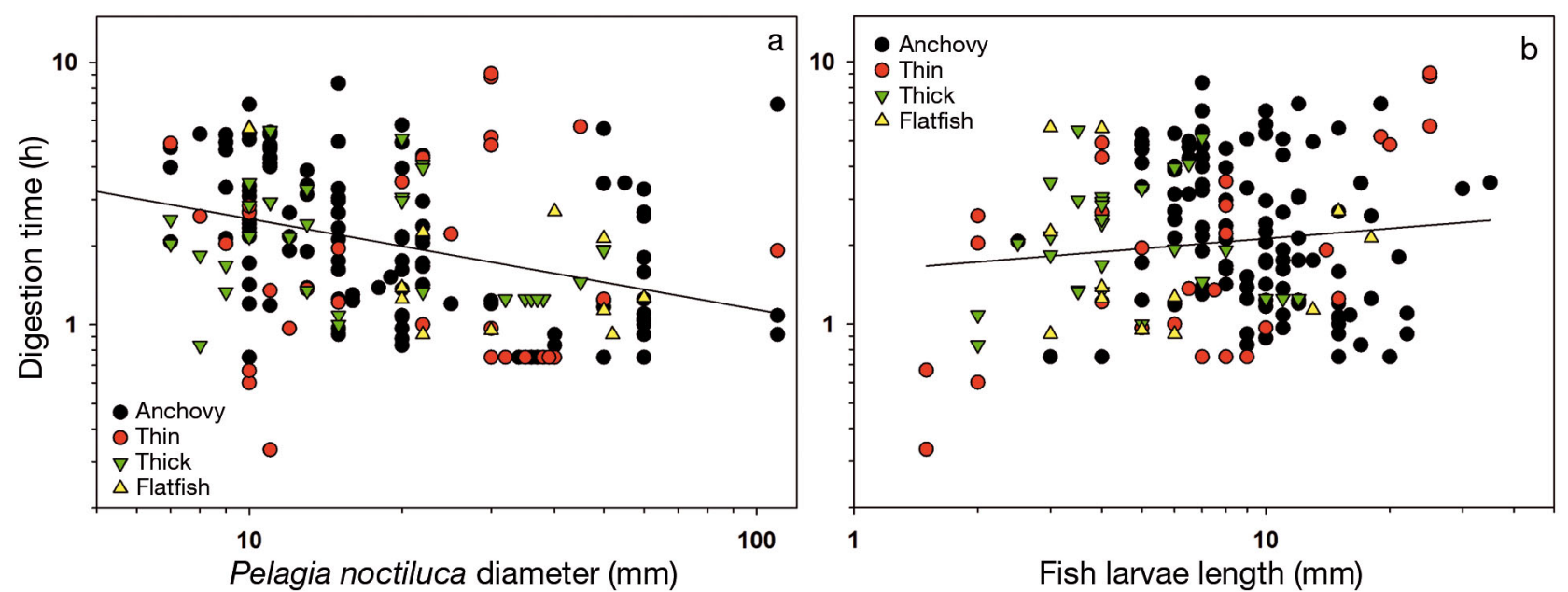

Fig. 1. Digestion times of Pelagia noctiluca medusae and ephyrae of fish larvae by type: anchovy Engraulis encrasicolus, thin larvae (sardinellas, gobies), thick larvae (carangids, sciaenids, serranids, scombrids), and flatfish Aroglossus laterna with respect to (a) P. noctiluca diameter, and (b) fish larvae length. Trend lines are best fit linear regressions for all larvae. See Table 2 for multiple regression equations

Table 3. Pelagia noctiluca ephyrae digestion time (DT) and recognition time (RT) of single fish larvae by taxon. Errors (\% of DT) are also given. Prey were anchovy Engraulis encrasicolus, serranid Serranus cabrilla, round sardinella Sardinella aurita, mackerel Trachurus mediterraneus, myctophid Ceratoscopelus maderensis, flatfish Aroglossus laterna, and unidentified gobies, sciaenids, and carangids. Data are presented as means $\pm \mathrm{SD}$, with ranges in parentheses. $\mathrm{T}$ : temperature

\begin{tabular}{|c|c|c|c|c|c|c|}
\hline $\begin{array}{l}\text { Jellyfish } \\
\text { Diameter (mm) }\end{array}$ & $\overline{\mathrm{n}}$ & $\mathrm{T}\left({ }^{\circ} \mathrm{C}\right)$ & $\begin{array}{l}\text { Fish larvae } \\
\text { length (mm) }\end{array}$ & DT (h) & Error (\%) & RT (h) \\
\hline $\begin{array}{l}\text { Ephyrae } \\
12.9 \pm 5.0 \\
(4-22)\end{array}$ & 64 & $\begin{array}{c}23.1 \pm 0.9 \\
(20.7-24.4)\end{array}$ & $\begin{array}{l}\text { Anchovy } \\
7.3 \pm 2.4 \\
(2.5-13.0)\end{array}$ & $\begin{array}{l}3.5 \pm 1.7 \\
(0.8-8.3)\end{array}$ & $\begin{array}{c}13.0 \pm 10.2 \\
(0-50)\end{array}$ & $\begin{array}{l}1.3 \pm 0.8 \\
(0.2-5.8)\end{array}$ \\
\hline $\begin{array}{l}13.2 \pm 0.6 \\
(9-13)\end{array}$ & 6 & $\begin{array}{c}24.2 \pm 0.2 \\
(23.7-24.4)\end{array}$ & $\begin{array}{c}\text { Serranid } \\
3.8 \pm 0.11 \\
(3.5-4.0)\end{array}$ & $\begin{array}{l}2.7 \pm 1.5 \\
(1.3-2.6)\end{array}$ & $\begin{array}{c}17.8 \pm 6.9 \\
(0-24)\end{array}$ & $\begin{array}{l}1.8 \pm 0.3 \\
(1.4-2.2)\end{array}$ \\
\hline $\begin{array}{l}13.3 \pm 4.2 \\
(10-22)\end{array}$ & 7 & $\begin{array}{c}23.7 \pm 0.2 \\
(23.3-24.4)\end{array}$ & $\begin{array}{c}\text { Round sardinella } \\
6.0 \pm 1.4 \\
(4.0-8.0) \\
\text { Goby }\end{array}$ & $\begin{array}{l}1.7 \pm 0.8 \\
(1.0-2.8)\end{array}$ & $\begin{array}{c}10.8 \pm 7.9 \\
(9-24)\end{array}$ & $\begin{array}{l}0.8 \pm 0.4 \\
(0.4-1.5)\end{array}$ \\
\hline $\begin{array}{l}9.8 \pm 2.8 \\
(8-15)\end{array}$ & 6 & $\begin{array}{c}24.1 \pm 0.5 \\
(23.5-24.4)\end{array}$ & $\begin{array}{l}2.2 \pm 0.9 \\
(1.5-4.0)\end{array}$ & $\begin{array}{l}1.2 \pm 0.9 \\
(0.5-2.7)\end{array}$ & $\begin{array}{c}35.0 \pm 18.2 \\
(6-50)\end{array}$ & $\begin{array}{l}0.6 \pm 0.3 \\
(0.3-1.1)\end{array}$ \\
\hline $\begin{array}{l}13.5 \pm 5.5 \\
(7-22)\end{array}$ & 24 & $\begin{array}{c}23.9 \pm 0.8 \\
(21.1-24.4)\end{array}$ & $\begin{array}{c}\text { Scombrid, sciaenid, carangid } \\
3.6 \pm 1.5 \\
(1.5-7.0)\end{array}$ & $\begin{array}{l}2.2 \pm 1.2 \\
(0.3-5.1)\end{array}$ & $\begin{array}{c}22.0 \pm 17.9 \\
(0-50)\end{array}$ & $\begin{array}{l}1.2 \pm 0.6 \\
(0.4-2.5)\end{array}$ \\
\hline $\begin{array}{l}17.3 \pm 5.8 \\
(10-22)\end{array}$ & 6 & $\begin{array}{c}23.8 \pm 0.7 \\
(23.0-24.4)\end{array}$ & $\begin{array}{l}\text { Flatfish } \\
3.5 \pm 0.6 \\
(3.0-4.0)\end{array}$ & $\begin{array}{l}2.8 \pm 2.2 \\
(0.9-5.6)\end{array}$ & $\begin{array}{c}14.9 \pm 19.0 \\
(0-50)\end{array}$ & $\begin{array}{l}1.3 \pm 1.2 \\
(0.2-3.2)\end{array}$ \\
\hline
\end{tabular}

other types of larvae were significantly different (Holm-Sidak method, $t=18.12$ to 29.63, p $<0.001$ ), and DTs of goby larvae also differed significantly from DTs of serranid and flatfish larvae $(t=3.08$ and 2.80 , respectively, $\mathrm{p}<0.01$ ). Thus, long, thin larvae (anchovies, sardinellas, gobies) were digested more rapidly than short, thick larvae (scombrids, carangids, serranids, flatfish; Fig. 1). The lengths of time that they were recognizable as fish larvae in the guts
(RTs) were approximately half of the DTs for both medusae and ephyrae.

Fish eggs were digested more slowly (1.2-44.8 h) than fish larvae by $P$. noctiluca ephyrae (Table 4, Fig. 2). About half of all eggs tested (29 of 56) were egested undigested after many hours, but interestingly, all anchovy eggs were digested. The sizes of ephyrae that had not digested eggs did not differ from those that had ( $t$-test, $t_{51}=1.445, \mathrm{p}=0.155$ ); 
Table 4. Pelagia noctiluca ephyrae digestion time (DT) and recognition time (RT) of single fish eggs by diameter. Eggs $0.8 \mathrm{~mm}$ in diameter are presented in 2 groups (anchovy and those other than anchovy). Retention times are for undigested eggs that were egested. Errors (\% of DT) are also given. Temperatures were $23.4 \pm 0.5^{\circ} \mathrm{C}\left(22.3-25.2^{\circ} \mathrm{C}\right)$. Data are presented as means \pm $\mathrm{SD}$, with ranges in parentheses. Percentages of each egg size digested are in square brackets. Errors reflect digested and undigested eggs; NA: not applicable

\begin{tabular}{|c|c|c|c|c|c|c|c|c|}
\hline \multirow{2}{*}{$\begin{array}{l}\text { Fish egg } \\
\text { diameter } \\
(\mathrm{mm})\end{array}$} & \multirow[b]{2}{*}{$\begin{array}{c}\text { Ephyra } \\
\text { (mm) }\end{array}$} & \multirow[b]{2}{*}{$\mathrm{n}$} & \multicolumn{3}{|c|}{ - Digested eggs } & \multicolumn{3}{|c|}{ _ Undigested eggs } \\
\hline & & & DT (h) & $\mathrm{RT}(\mathrm{h})$ & Error $(\%)$ & $\begin{array}{c}\text { Ephyra } \\
\text { (mm) }\end{array}$ & $\mathrm{n}$ & $\begin{array}{l}\text { Retention } \\
\text { (h) }\end{array}$ \\
\hline $0.6[75 \%]$ & $\begin{array}{c}9.9 \pm 3.1 \\
(7-15)\end{array}$ & 9 & $\begin{array}{c}8.2 \pm 2.2 \\
(4.3-10.6)\end{array}$ & $\begin{array}{l}6.1 \pm 2.1 \\
(3.2-9.5)\end{array}$ & $\begin{array}{c}15.8 \pm 2.2 \\
(13-20)\end{array}$ & $\begin{array}{c}8.7 \pm 1.5 \\
(7-10)\end{array}$ & 3 & $\begin{array}{c}12.1 \pm 6.3 \\
(5.2-17.5)\end{array}$ \\
\hline $0.8[45.2 \%]$ & $\begin{array}{c}12.1 \pm 4.3 \\
(8-22)\end{array}$ & 14 & $\begin{array}{c}17.4 \pm 12.0 \\
(3.8-44.8)\end{array}$ & $\begin{array}{c}14.8 \pm 13.0 \\
(2.3-43.0)\end{array}$ & $\begin{array}{c}19.0 \pm 18.8 \\
(6-50)\end{array}$ & $\begin{array}{c}9.8 \pm 3.7 \\
(5-20)\end{array}$ & 17 & $\begin{array}{l}12.6 \pm 7.9 \\
(2.8-29.2)\end{array}$ \\
\hline 0.8 anchovy [100\%] & $\begin{array}{c}9.7 \pm 0.5 \\
(9-10)\end{array}$ & 6 & $\begin{array}{c}8.5 \pm 5.4 \\
(1.2-17.8)\end{array}$ & $\begin{array}{c}6.3 \pm 3.1 \\
(4.5-12.5)\end{array}$ & $\begin{array}{c}19.8 \pm 6.2 \\
(15-30)\end{array}$ & NA & 0 & NA \\
\hline $1.0[0 \%]$ & $\begin{array}{c}8.0 \pm 1.0 \\
(7-9)\end{array}$ & 0 & NA & NA & NA & $\begin{array}{c}8.0 \pm 1.4 \\
(7-9)\end{array}$ & 2 & $\begin{array}{c}22.7 \pm 1.0 \\
(22.0-23.4)\end{array}$ \\
\hline $1.1[0 \%]$ & $\begin{array}{c}13.3 \pm 6.5 \\
(7-20)\end{array}$ & 0 & NA & NA & NA & $\begin{array}{c}15.0 \pm 5.1 \\
(10-22)\end{array}$ & 6 & $\begin{array}{c}3.0 \pm 0.9 \\
(1.8-4.2)\end{array}$ \\
\hline
\end{tabular}
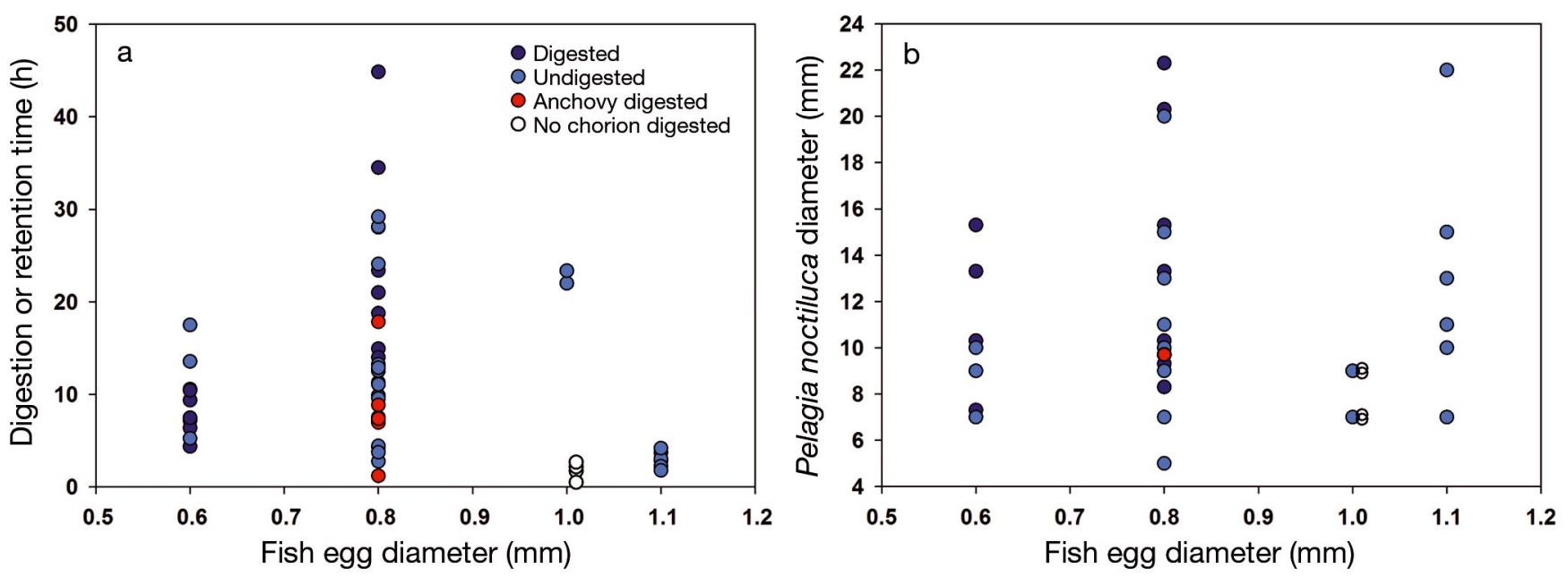

Fig. 2. (a) Pelagia noctiluca ephyral digestion and retention times of fish eggs with respect to egg diameter. Time (h) that eggs were inside ephyrae. (b) Size of ephyrae compared to size of digested and undigested eggs. In (b), ephyral diameters for digested eggs were offset by $+0.3 \mathrm{~mm}$ and only 1 point is shown for anchovy (of 6 at $9-10 \mathrm{~mm}$ ) to enable them to be better seen

thus, small ephyral size did not explain why some eggs were not digested. Similarly, egg sizes did not differ between those digested or undigested (MannWhitney $U=296.50, \mathrm{p}=0.194$ ) although no 1.0 or $1.1 \mathrm{~mm}$ eggs were digested. To test whether eggs would be digested without the chorion, it was dissected from 4 of the $1 \mathrm{~mm}$ eggs, which otherwise were not digested by ephyrae. These embryos were digested rapidly by the ephyrae $(1.78 \pm 0.46 \mathrm{~h}$; Fig. 2), suggesting that the chorion protected the eggs from digestion. DTs of eggs differed significantly by diameter $\left(F_{3,29}=5.68, \mathrm{p}=0.003\right)$, with $0.8 \mathrm{~mm}$ eggs requiring longer to digest than all others. One $3 \mathrm{~mm}$ diameter egg was digested in $22.4 \mathrm{~h}$ by a $22 \mathrm{~mm}$ ephyra. Neither DTs nor RTs of undigested eggs were significantly related to ephyral size, $\mathrm{T}$, or egg size $\left(F_{3,28}=1.071, \mathrm{p}=0.377\right.$ and $F_{3,22}=$ $0.622, p=0.608$, respectively). RT of digested fish eggs were $75-85 \%$ of the DT for ephyrae, and RT of undigested eggs were $100 \%$ of retention times.

DT and RT of copepods could only be measured for ephyrae (Table 2). DTs of single copepods by ephyrae averaged $4 \mathrm{~h}$ and were not significantly related to prey or ephyral size, or T. We gave 2 to 4 copepods only to 4 ephyrae, but average digestion time remained $\sim 4 \mathrm{~h}$. RTs of copepods were about half of the DTs for ephyrae.

Salps were very abundant and were eaten by medusae in 2011 (J. E. Purcell pers. obs.). DTs of large salps Salpa fusiformis by medusae averaged $2 \mathrm{~h}$ and 
were significantly related to salp length and temperature (Table 2). The few salps Thalia democratica small enough to be ingested by ephyrae were digested in $\sim 3 \mathrm{~h}$.

P. noctiluca eats a variety of zooplankton, but digestion times previously were unavailable. DTs of euphausiids ( $\mathrm{n}=10,10-20 \mathrm{~mm}$ TL) by medusae averaged $5.0 \pm 2.4 \mathrm{~h}$. Velella velella colonies were eaten by medusae in situ (V. L. Fuentes et al. pers. obs.). DTs of 15 and $26 \mathrm{~mm}$ long colonies by 2 medusae were $\sim 3.7 \mathrm{~h}$, and those of 1 to $3 \mathrm{~mm}$ long colonies by 4 ephyrae were $\sim 5.3 \mathrm{~h}$. The chitin sail of $V$. velella was still recognizable after egestion. The nectophores of 2 polygastric colonies of the siphonophore Muggiaea atlantica were egested with their firm mesoglea intact from medusae after 5.0 and $6.5 \mathrm{~h}$. Cladocerans (Penilia sp. and Podon sp.) were digested by ephyrae in $3.0 \pm 1.7 \mathrm{~h}(\mathrm{n}=17)$. DTs of euphausiid furcilia larvae $(\mathrm{n}=13,3-11 \mathrm{~mm} \mathrm{TL})$ for ephyrae averaged $5.0 \pm 0.9 \mathrm{~h}$. DTs by ephyrae were short for 2 appendicularians $(<1 \mathrm{~h})$ and 1 chaetognath $(1-2 \mathrm{~h})$. Coiled pteropods $(\mathrm{n}=3,0.5 \mathrm{~mm})$, whose shells were recognizable until egestion, were digested in $\sim 4 \mathrm{~h}$ by ephyrae. RTs of the crustaceans were 45 to $65 \%$ of DTs. RTs of shelled pteropods and the cnidarians were $100 \%$ of DT.

\section{DISCUSSION}

\section{Digestion and recognition times}

Gut contents of gelatinous predators in combination with DT can be used to determine in situ predation rates (prey consumed predator ${ }^{-1}$ time $^{-1}$ ), and in combination with population densities of the predators and prey, they can be used to estimate predation effects (\% prey consumed time ${ }^{-1}$ ). Even though Pelagia noctiluca blooms in tropical to temperate oceans around the world (Kramp 1961), few studies exist on DT. Gordoa et al. (2013) mentioned $18 \pm 5 \mathrm{~h}$ as the DT of bluefin tuna Thunnus thynnus eggs by 'burst feeding' $P$. noctiluca ephyrae. We also only know the DT for $P$. noctiluca medusae consuming Mnemiopsis lei$d y i$ ctenophores (Tilves et al. 2012).

Martinussen \& Båmstedt (2001) comprehensively summarized earlier studies on DTs of fish larvae, fish eggs, and zooplankton by gelatinous predators. The DTs of fish larvae in our study were similar to those in other studies that included larvae and medusae of comparable sizes, even when the temperatures were $10^{\circ} \mathrm{C}$ lower (Table 5). Few DTs were available for fish eggs, and no other studies used ephyrae and eggs.
DT of anchovy eggs by Chrysaora quinquecirrha medusae (3.7-5.2 h, mean $4 \mathrm{~h})$ and Stomolophus meleagris $(3 \mathrm{~h}$ ) were within the range for $P$. noctiluca ephyrae (1.2-17 h, mean $8.5 \mathrm{~h})$, but shorter on average. DTs of $\sim 1 \mathrm{~mm}$ copepods by $P$. noctiluca ephyrae were similar to those of other species of comparable sizes even at temperatures that were $10^{\circ} \mathrm{C}$ lower (Table 5). Our results are also comparable to other species digesting cladocerans and appendicularians. The cladoceran Evadne sp. was digested by Aurelia aurita ephyrae in $3.4 \mathrm{~h}$ at $4-5^{\circ} \mathrm{C}$ (Sullivan et al. 1997). Digestion of appendicularians was very rapid by hydromedusae ( $<2 \mathrm{~h}$; Larson $1987 \mathrm{~b})$ and by $S$. meleagris at $28-30^{\circ} \mathrm{C}(1.5 \mathrm{~h}$; Larson 1991). We are unaware of other DTs for gelatinous predators of salps, pteropods, or stages of euphausiids other than eggs or nauplii (see Martinussen \& Båmstedt 2001).

Our estimates of DT and RT in P. noctiluca were constrained by the numbers and sizes of medusae available and the relatively narrow range of ambient seawater temperature. Too few medusae were present to allow repeated microscopic analysis to follow digestion over time, which could have damaged the specimens, or to preserve them for gut analysis to confirm complete digestion or recognition. P. noctiluca inhabits a wide range of temperatures from deep waters at $<14^{\circ} \mathrm{C}$ to the surface at $>26^{\circ} \mathrm{C}$ in the Mediterranean Sea. Therefore, DT and RT should be measured over that range of temperatures, which large medusae traverse on daily vertical migrations. Because we followed prey items in swimming medusae, 2 problems resulted. First, the end-point of digestion was usually very subjective. Second, we were unable to measure digestion of small prey (copepods, most fish larvae, and fish eggs) by medusae; therefore, additional experiments need to be conducted in which digestion of prey can be monitored more precisely. Our study was also limited by monitoring digestion of single prey items. Because of their small size, ephyrae may not catch several prey items concurrently (but see Fig. 3); however, medusae usually contain numerous prey (J. E. Purcell \& U. Tilves pers. obs.), which affected DT measured for small A. aurita (Martinussen \& Båmstedt 2001, FitzGeorge-Balfour et al. 2013).

The lack of digestion of about $50 \%$ of the fish eggs by ephyrae raised interesting questions. Although small ephyral size did not explain that phenomenon (Fig. 2b), we could not measure digestion of fish eggs by medusae because we could not visually follow such small prey inside them. As ephyrae grew, the number and length of the digestive filaments in the gastric pouches increased (J. E. Purcell pers. obs.). 
Table 5. Selected studies reporting digestion times (DT) for medusae and ctenophores eating fish larvae or eggs and copepods. The percentages of the standing stocks consumed and percentages of prey in the gut contents also reported if available. If more than

1 prey item was digested, the numbers are given in parentheses. T: temperature; NG: not given; lg: large; sm: small; n: number

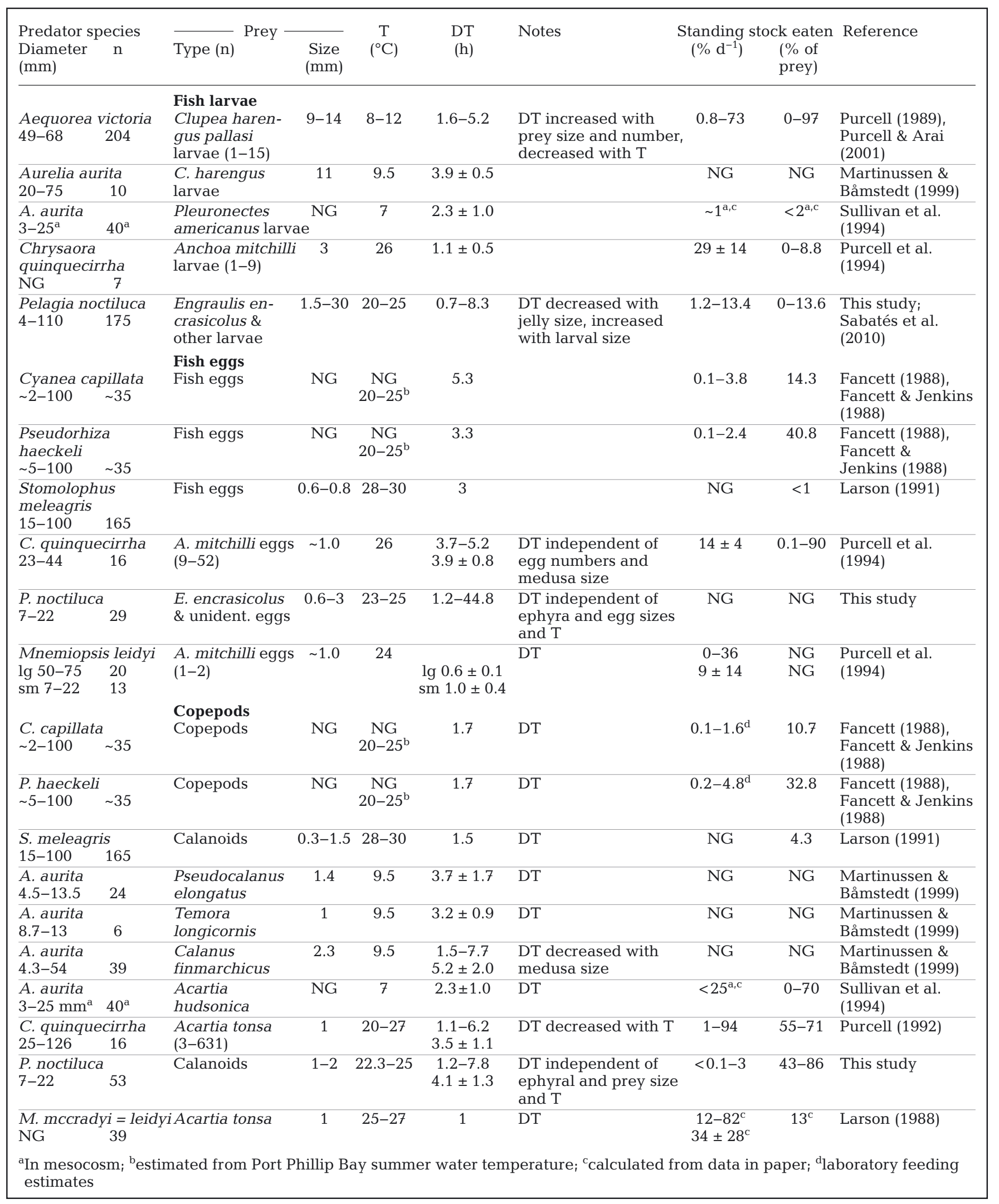






Fig. 3. Pelagia noctiluca ephyra collected from the surface at night and immediately preserved on 4 July 2011. The ephyra contained 2 anchovy larvae ( 10 $\mathrm{mm}$ long) and 1 unidentified fish egg ( $0.9 \mathrm{~mm}$ diameter; indicated by arrow). Ephyra preserved diameter is $7 \mathrm{~mm}$

The ephyrae collected by Sabatés et al. (2010) did not contain any fish eggs, although they were available for consumption (A. Sabatés pers. obs.). Therefore, we do not know whether $P$. noctiluca medusae $>22 \mathrm{~mm}$ would digest all fish eggs.

On the other hand, the fish eggs may be resistant to digestion. Baltic cod Gadus morhua callariasadus eggs were rejected by $M$. leidyi ctenophores; ctenophores that had ingested eggs subsequently ejected 12 of 14 eggs undigested after $2 \mathrm{~h}$ at $22^{\circ} \mathrm{C}$ and $3 \mathrm{~d}$ at $7^{\circ} \mathrm{C}$ (Jaspers et al. 2011). Plaice Pleuronectes platessa eggs similarly were ingested, but were egested undigested 'after some hours' by Bolinopsis infundibulum ctenophores (Gamble 1977). Most (98-99\%) bivalve veligers were not digested or killed by C. quinquecirrha medusae (Purcell et al. 1991). 'Passing alive' of pelagic larvae of benthic invertebrates through their predators has been described previously (Mileikovsky 1974), but we could find no further information about fish eggs. Unfortunately, we were unable to determine whether the eggs had been killed by the ephyrae or remained viable.

\section{Potential predation effects by Pelagia noctiluca on fish larvae and copepods}

The DT and RT of $P$. noctiluca are valuable instruments for estimating predation on prey populations in situ. We, therefore, chose a study conducted in the Catalan Sea (Sabatés et al. 2010) to illustrate this method and problems we encountered. In the Sabatés et al. (2010) study, sampling was conducted on a tran- sect perpendicular to the coast at 3 stations (Shelf: over the shelf; Front: over the slope at a shelf-break front; Open Sea: in the open sea) during 18 to 23 June 1995. Sampling was repeated 3 times at each station, and temperature was measured at each station with a CTD. Zooplankton, jellyfish, and fish larvae were sampled by oblique tows of a $60 \mathrm{~cm}$ diameter bongo net with a flowmeter and $500 \mathrm{~m}$ mesh from nearbottom $(70-80 \mathrm{~m})$ to the surface over the shelf or from $200 \mathrm{~m}$ to the surface at the front and in the open sea $(\geq 1000 \mathrm{~m}$ depth). The duration of the tows ranged from 6 min at shallow shelf stations to $23 \mathrm{~min}$ at the front and open sea stations. Net samples were fixed in a $5 \%$ formaldehyde-seawater solution. $P$. noctiluca ephyrae ( $\leq 12 \mathrm{~mm}$ diameter), and fish larvae were counted and identified to the lowest possible taxonomic level from whole preserved samples aided by a dissecting microscope. All copepods were counted from 1/256 to $1 / 32$ aliquots obtained with a plankton splitter. The gut contents of all ephyrae in the samples were identified, counted, and measured; only partly digested prey were included to ensure that the prey items had not been captured while in the net.

Although Sabatés et al. (2010) presented average predation by location (Shelf, Front, Open Sea), we calculated feeding at each of the 3 stations per location. Individual feeding rates of $P$. noctiluca ephyrae on fish larvae and copepods were calculated from the numbers of each prey type in the gut contents at each station divided by the DT of 107 fish larvae or 53 copepods at the mean surface water temperature in $1995\left(20.4^{\circ} \mathrm{C}\right)$, as calculated from mean prey sizes and regression equations in Table 2. Individual feeding rates were multiplied by ephyral densities and divided by prey densities at each station to estimate the effects of the ephyrae on the prey populations (\% prey standing stock consumed $\mathrm{h}^{-1}$ ). To estimate the potential daily predation at each location, we assumed that feeding and digestion were continuous over the $8 \mathrm{~h}$ periods represented by the samples at each location (day, dawn/dusk, night) and multiplied the hourly rates by 8 and then summed the 3 stations.

Estimates of potential predation by ephyrae on fish larvae were highly variable among the 9 stations (Fig. 4). Ephyrae were much more abundant $\left(13.4 \mathrm{~m}^{-3}\right)$ at the Front at night $(01: 00 \mathrm{~h})$ than at other stations $\left(<1 \mathrm{~m}^{-3}\right)$. The incidences of feeding (ephyrae with prey) at the Front were only 6 to $13 \%$, probably reflecting damage to the ephyrae and loss of prey in the $200 \mathrm{~m}$ depth tows. Fish larvae were of average abundance at that station, and the highest levels of predation $\left(3.7 \%\right.$ of the larvae $\left.\mathrm{h}^{-1}\right)$ occurred there at night (Fig. 4). Although ephyrae were found at low 

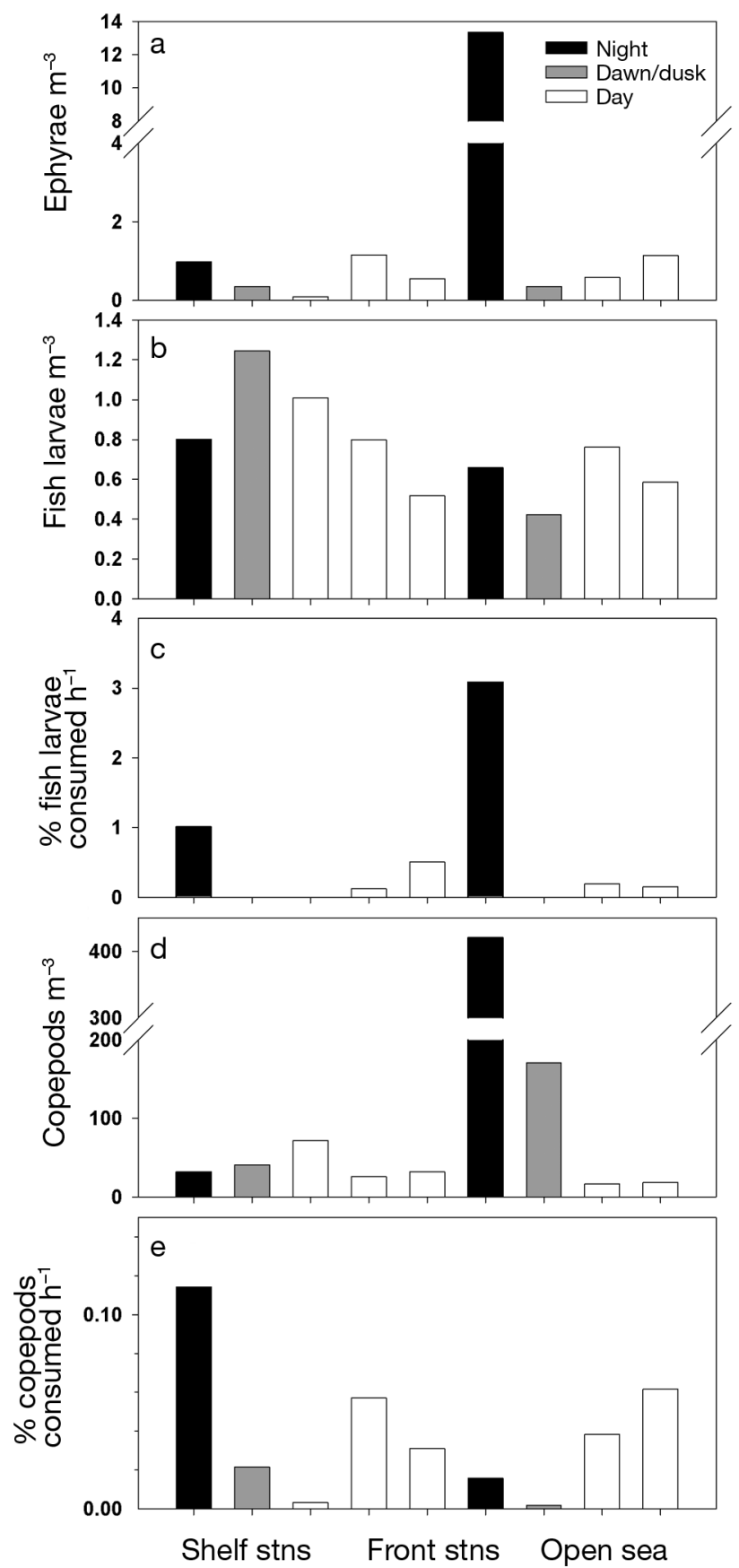

Fig. 4. Abundances and predation effects of Pelagia noctiluca ephyrae on fish larvae and copepods according to station (stn) and time of day in the northwestern Mediterranean Sea during 18 to 23 June 1995. Three stations each were over the shelf, at a shelf-break front, or in the open sea along a transect perpendicular to the coast. (a) Ephyrae densities, (b) fish larvae densities, (c) predation effects on fish larvae, (d) copepod densities, and (d) predation effects on copepods

densities on the Shelf $\left(0-0.03 \mathrm{~m}^{-3}\right)$, fish larval densities were highest there $\left(0.8-1.2 \mathrm{~m}^{-3}\right)$, and feeding incidences were high (14-33\%) where tows were from only 70 to $80 \mathrm{~m}$ depth. Fish larvae were found in
Table 6. Estimated potential predation effects (\% prey consumed $\mathrm{d}^{-1}$ ) of Pelagia noctiluca ephyrae on fish larvae and copepods in the northwest Mediterranean Sea in June 1995

\begin{tabular}{|lcrcc|}
\hline Prey type & Location & $\begin{array}{c}\text { Prey in } \\
\text { guts } \\
\text { (n) }\end{array}$ & $\begin{array}{c}\text { Ephyrae } \\
\text { examined } \\
(\mathrm{n})\end{array}$ & $\begin{array}{c}\text { Prey } \\
\text { consumed } \\
\left(\% \mathrm{~d}^{-1}\right)\end{array}$ \\
\hline Fish larvae & Shelf & 2 & 145 & 3.6 \\
& Front & 26 & 4400 & 13.4 \\
& Open sea & 5 & 1135 & 1.2 \\
Copepods & Shelf & 18 & 145 & 0.42 \\
& Front & 110 & 4400 & 0.31 \\
& Open sea & 48 & 1135 & 0.31 \\
\hline
\end{tabular}

the ephyrae only at night (22:00 h) on the Shelf, when we estimated that $1.2 \% \mathrm{~h}^{-1}$ could have been consumed. In the Open Sea, ephyral densities, feeding incidences $(9-10 \%$ in $200 \mathrm{~m}$ tows $)$, and predation effects were low $\left(0-0.7 \% \mathrm{~h}^{-1}\right.$; Fig. 4$)$. Daily potential predation effects on fish larvae at each location ranged from 1.2 to $13.4 \% \mathrm{~d}^{-1}$; Table 6 ).

Estimated potential predation effects by $P$. noctiluca ephyrae on copepods were much lower than on fish larvae (Fig. 4). Although copepods were very abundant at the Front station at night, the estimated potential predation effect was low $\left(0.05 \% \mathrm{~h}^{-1}\right)$ because of the low feeding incidence. The highest predation effect $\left(0.11 \% \mathrm{~h}^{-1}\right)$ was at night on the shelf, again probably because of the high feeding incidence $(25 \%)$. The daily potential predation effects on copepods at each station ranged from 0.30 to $0.42 \% \mathrm{~d}^{-1}$; Table 6). The predation effects of ephyrae on copepods were much lower $\left(\leq 0.42 \% \mathrm{~d}^{-1}\right)$ than on fish larvae $\left(\leq 13.4 \% \mathrm{~d}^{-1}\right)$ due to the 50 - to 500 -fold greater densities of copepods.

Even though the sampling methods of Sabatés et al. (2010) were standard for fisheries oceanography, they illustrated some problems for estimating predation effects on fish larvae by $P$. noctiluca. First, we believe that the net sampling damaged the ephyrae and reduced their apparent feeding. That was indicated by the higher feeding incidence on the shallow shelf where tows were half as deep as at the other stations. This likelihood also was clearly illustrated by the gut contents of ephyrae dipped from the surface in 2011 to 2012 (Fig. 3), which contained fish eggs and more fish larvae than in 1995. Additionally, the $60 \mathrm{~cm}$ diameter net was too small to adequately sample the larger medusae. Thus, feeding by P. noctiluca was underestimated with these net samples.

Other biases in the predation estimates resulted because the oblique tows of Sabatés et al. (2010) obscured the diel vertical migration patterns of $P$. noc- 
tiluca and their prey. The medusae are known to migrate near to the surface at night (Ferraris et al. 2012), and the ephyrae move near the surface during the night (Gordoa et al. 2013; V. L. Fuentes et al. pers. obs.). Anchovy larvae also migrate towards the surface at night (Sabatés et al. 2008). Thus, the oblique net tows in 1995 did not reflect the fine-scale patterns of overlap of ephyrae and larvae over $24 \mathrm{~h}$, which were not known, but may have extended the duration of overlap. The variable sampling times at the different stations in 1995 also made predation estimates difficult to compare. If we had used RT instead of DT to calculate predation effects, the effects would have been approximately doubled. We consider the predation estimates presented here to be rough approximations.

Thus, our recommendations for use of the gutcontent method to estimate gelatinous predator consumption of ichthyoplankton and mesozooplankton are as follows:

- Collect specimens for gut contents individually, not in plankton nets, and preserve them immediately.

- Collect gut-content specimens from all appropriate depths, not only at the surface.

- Appropriate sampling methods should be chosen with consideration of the depth distribution patterns of predator and prey species during day and night.

- Use ambient temperature to measure digestion and recognition times.

- Different digestion methods may be best depending on predator and prey characteristics (e.g. Purcell et al. 1991, FitzGeorge-Balfour et al. 2013).

- The duration between ingestion and when prey can still be recognized in microscopic gut-content analysis (RT) is the most appropriate measure for use in feeding estimates using gut contents.

- Use data for ephyral size and ichthyoplankton species and size consumed for greatest accuracy.

- Determine densities, depths, and size distributions of the gelatinous species and their prey to estimate predation effects (\% prey standing stock consumed $\mathrm{d}^{-1}$ ).

\section{Effects of gelatinous zooplankton as predators and competitors of fish}

Surprisingly few studies have addressed consumption of fish eggs and larvae by gelatinous predators in situ. Whenever such studies were conducted, the predation effects were substantial (reviewed by Purcell 1985, Purcell \& Arai 2001). Ichthyoplankton often constitutes large proportions of prey found in the gut contents (Table 5). P. noctiluca ephyrae and medusae could be important predators of fish eggs and larvae. Larson (1987a) stated that fish eggs were the most numerous prey items in 50 medusae, with as many as 10 eggs medusa ${ }^{-1}$. Sabatés et al. (2010) found that fish larvae represented $\sim 12 \%$ of the prey items in ephyral gut contents in the spring. Fish larvae and eggs represented 0.2 and $1.1 \%$, respectively, of the prey in medusae collected throughout a year (Rosa et al. 2013). Gelatinous predators have been demonstrated to reduce populations of fish larvae (Purcell \& Grover 1990).

Gelatinous predators consume a variety of fish species in the plankton, including commercially valuable species. The siphonophore Rhizophysa eysenhardti consumed fish larvae in 5 families (Purcell 1981). The scyphomedusae Cyanea capillata and Pseudorhiza haeckeli consumed 4 kinds of larvae and eggs (Fancett 1988). S. meleagris consumed 4 kinds of eggs (Larson 1991). Similarly, the large hydromedusan Aequorea victoria consumed larvae of at least 10 species of fishes and eggs of at least 3 species (Purcell 1989). Eight species of larvae were eaten by P. noctiluca ephyrae (Sabatés et al. 2010). Additional studies conducted since the reviews by Purcell (1985) and Purcell \& Arai (2001) have shown that the cubomedusae Chironex fleckeri, Tamoya haplonema, and Chiropsalmus quadrumanus eat fish (Carrette et al. 2002, Nogueira Júnior \& Haddad 2008). Young fish and fish eggs represented 5.2 and $1.2 \%$, respectively, of the prey items in the pleustonic hydrozoan Velella velella (Purcell et al. 2012). Thus, the potential effects of gelatinous predators on fish are great.

Mesozooplankters are the main components of the diets of many fish and pelagic cnidarians and ctenophores, and dietary overlaps have been shown (Purcell \& Grover 1990, Purcell \& Sturdevant 2001, Brodeur et al. 2008). The small percentages of the copepod standing stocks consumed by $P$. noctiluca ephyrae may seem unimportant, but the combined predation of the suite of gelatinous predators (Fuentes et al. 2010, Sabatés et al. 2010, Canepa et al. 2014) removes food that otherwise could be consumed by fish. Studies of in situ predation by gelatinous species eating mesozooplankton are more numerous than studies on ichthyoplankton (e.g. Larson 1987b, 1988, Purcell 1997, 2009). Predation effects on mesozooplankton, primarily copepods, vary greatly depending on the abundance of the predators (summarized by Purcell \& Arai 2001). Competition for prey requires that prey are limiting, and when abundant, pelagic cnidarians and ctenophores can reduce copepod populations (e.g. Purcell \& Decker 2005).

We believe that existing evidence of gelatinous species as important predators of ichthyoplankton 
and mesozooplankton covers only a small fraction of the extent of their predation. Past studies have considered only a few of the $>1400$ species of gelatinous predators that inhabit all depths of estuaries and oceans (Purcell et al. 2007). The studies were conducted only in near-surface waters, whereas concentrations of ichthyoplankton, mesozooplankton, and predators often occur at sub-surface hydrographic discontinuities (clines) (Graham et al. 2001, Purcell et al. 2014). The studies have also been limited spatially and temporally. Although P. noctiluca has been studied in only a few locations, primarily in Irish waters (Doyle et al. 2008, Bastian et al. 2011) and the Mediterranean Sea, this species is found in tropical to temperate oceans around the world (Kramp 1961). Studies suggest that blooms of $P$. noctiluca and other species have increased in frequency and duration in the Mediterranean Sea (Daly Yahia et al. 2010, Kogovšek et al. 2010, Licandro et al. 2010, Bernard et al. 2011). If cnidarian and ctenophore populations increase around the world, as evidence from some locations suggests (Brotz et al. 2012, Condon et al. 2013), there could be increasing predation on ichthyoplankton and mesozooplankton and increasing detrimental effects on fish populations.

Acknowledgements. We greatly appreciate the assistance of the crew of the RV 'García del Cid' and all the participants during the cruises. This study was supported by the project MAR-CTM2010-18874. V.L.F. was funded by a JAE-DOC contract of CSIC co-financed by the FSE (European Social Fund).

\section{LITERATURE CITED}

Bailey KM, Houde ED (1989) Predation on eggs and larvae of marine fishes and the recruitment problem. Adv Mar Biol 25:1-83

Bastian T, Stokes D, Kelleher JE, Hays GC, Davenport J, Doyle TK (2011) Fisheries bycatch data provide insights into the distribution of the mauve stinger (Pelagia noctiluca) around Ireland. ICES J Mar Sci 68:436-443

Bernard P, Berline L, Gorsky G (2011) Long term (1981-2008) monitoring of the jellyfish Pelagia noctiluca (Cnidaria, Scyphozoa) on Mediterranean Coasts (Principality of Monaco and French Riviera). J Oceanogr Res Data 4:1-10

- Brodeur RD, Suchman CL, Reese DC, Miller TW, Daly EA (2008) Spatial overlap and trophic interactions between pelagic fish and large jellyfish in the northern California Current. Mar Biol 154:649-659

Brotz L, Cheung WWL, Kleisner K, Pakhomov E, Pauly D (2012) Increasing jellyfish populations: trends in Large Marine Ecosystems. Hydrobiologia 690:3-20

Canepa A, Fuentes V, Sabatés A, Piraino S, Boero F, Gili JM (2014) Pelagia noctiluca in the Mediterranean Sea. In: Pitt KA, Lucas CH (eds) Jellyfish blooms. Springer Science+Business Media, Dordrecht, p 237-266
Carrette T, Alderslade P, Seymour J (2002) Nematocyst and prey in two Australian cubomedusans, Chironex fleckeri and Chiropsalmus sp. Toxicon 40:1547-1551

Condon RH, Duarte CM, Pitt KA, Robinson KL and others (2013) Recurrent jellyfish blooms are a consequence of global oscillations. Proc Natl Acad Sci USA 110:1000-1005

Daly Yahia MN, Batistic M, Lu i D, Fernández de Puelles ML and others (2010) Are outbreaks of Pelagia noctiluca (Forskål, 1771) more frequent in the Mediterranean basin? ICES Coop Rep 300:8-14

Doyle TK, De Haas H, Cotton D, Dorschel B and others (2008) Widespread occurrence of the jellyfish Pelagia noctiluca in Irish coastal and shelf waters. J Plankton Res 30:963-968

- Fancett MS (1988) Diet and prey selectivity of scyphomedusae from Port Phillip Bay, Australia. Mar Biol 98:503-509

Fancett MS, Jenkins GP (1988) Predatory impact of scyphomedusae on ichthyoplankton and other zooplankton in Port Phillip Bay. J Exp Mar Biol Ecol 116:63-77

Ferraris M, Berline L, Lombardi F, Guidi L and others (2012) Distribution of Pelagia noctiluca (Cnidaria, Scyphozoa) in the Ligurian Sea (NW Mediterranean Sea). J Plankton Res 34:874-885

FitzGeorge-Balfour T, Hirst AG, Lucas CH, Craggs J, Whelan EJ, Mombrikotb S (2013) Estimating digestion time in gelatinous predators: a methodological comparison with the scyphomedusae Aurelia aurita. Mar Biol 160:793-804

> Fuentes VL, Angel DL, Bayha KM, Atienza D and others (2010) Blooms of the invasive ctenophore, Mnemiopsis leidyi, span the Mediterranean Sea in 2009. Hydrobiologia 645:23-37

Gamble JC (1977) Population structure, feeding, behavior, and fecundity of the lobate ctenophore Bolinopsis infundibulum. International Council for the Exploration of the Sea, Copenhagen

Gordoa A, Acuña JL, Farrés R, Bacher K (2013) Burst feeding of Pelagia noctiluca ephyrae on Atlantic bluefin tuna (Thunnus thynnus) eggs. PLoS ONE 8:e74721

Goy J, Morand P, Etienne M (1989) Long-term fluctuations of Pelagia noctiluca (Cnidaria, Scyphomedusae) in the western Mediterranean Sea. Prediction by climatic variables. Deep-Sea Res 36:269-279

> Graham WM, Pagès F, Hamner WM (2001) A physical context for gelatinous zooplankton aggregations: a review. Hydrobiologia 451:199-212

Hjort J (1914) Fluctuations in the great fisheries of northern Europe viewed in the light of biological research. Rapp P V Reùn Cons Int Explor Mer 20:1-228

Houde ED (2008) Emerging from Hjort's shadow. J Northwest Atl Fish Sci 41:53-70

Jaspers C, Titelman J, Hansson LJ, Haraldsson M, Ditlefsen CR (2011) The invasive ctenophore Mnemiopsis leidyi poses no direct threat to Baltic cod eggs and larvae. Limnol Oceanogr 56:431-439

Kogovšek T, Bogunovi B, Malej A (2010) Recurrence of bloom-forming scyphomedusae: wavelet analysis of a 200-year time-series. Hydrobiologia 645:81-96

Kramp PL (1961) Synopsis of the medusae of the world. J Mar Biol Assoc UK 40:1-469

Larson RJ (1987a) A note on the feeding, growth, and reproduction of the epipelagic scyphomedusa Pelagia noctiluca (Forsskål). Biol Oceanogr 4:447-454

> Larson RJ (1987b) Daily ration and predation by medusae and ctenophores in Saanich Inlet, B.C., Canada. Neth J Sea Res 21:35-44 
Larson RJ (1988) Feeding and functional morphology of the lobate ctenophore Mnemiopsis mccradyi. Estuar Coast Shelf Sci 27:495-502

Larson RJ (1991) Diet, prey selection and daily ration of Stomolophus meleagris, a filter-feeding scyphomedusa from the NE Gulf of Mexico. Estuar Coast Shelf Sci 32: 511-525

- Licandro P, Conway DVP, Daly Yahia MN, Fernandez de Puelles ML and others (2010) A blooming jellyfish in the northeast Atlantic and Mediterranean. Biol Lett 6: 688-691

Malej A (1982) Unusual occurrence of Pelagia noctiluca in the Adriatic Sea. Acta Adriat 23:97-102 (in Slovenian)

Mariottini GL, Giacco E, Pane L (2008) The mauve stinger Pelagia noctiluca (Forsskål, 1775). Distribution, ecology, toxicity and epidemiology of stings. A review. Mar Drugs 6:496-513

Martinussen MB, Båmstedt U (1999) Nutritional ecology of gelatinous planktonic predators. Digestion rate in relation to type and amount of prey. J Exp Mar Biol Ecol 232: 61-84

Martinussen MB, Båmstedt U (2001) Digestion rate in relation to temperature of two gelatinous planktonic predators. Sarsia 86:21-35

Mileikovsky SA (1974) On predation of pelagic larvae and early juveniles of marine bottom invertebrates by adult benthic invertebrates and their passing alive through their predators. Mar Biol 26:303-311

Nogueira Júnior M, Haddad MA (2008) The diet of cubomedusae (Cnidaria, Cubozoa) in southern Brazil. Brazil J Oceanogr 56:157-164

Pepin P (1995) An analysis of the length-weight relationship of larval fish: limitations of the general allometric model. Fish Bull 93:419-426

Purcell JE (1981) Feeding ecology of Rhizophysa eysenhardti, a siphonophore predator of fish larvae. Limnol Oceanogr 26:424-432

Purcell JE (1985) Predation on fish eggs and larvae by pelagic cnidarians and ctenophores. Bull Mar Sci 37: 739-755

> Purcell JE (1989) Predation by the hydromedusa Aequorea victoria on fish larvae and eggs at a herring spawning ground in British Columbia. Can J Fish Aquat Sci 46: 1415-1427

Purcell JE (1992) Effects of predation by the scyphomedusan Chrysaora quinquecirrha on zooplankton populations in Chesapeake Bay, USA. Mar Ecol Prog Ser 87:65-76

Purcell E (1997) Pelagic cnidarians and ctenophores as predators: selective predation, feeding rates and effects on prey populations. Ann Inst Oceanogr Paris (Nouv Ser) 73: 125-137

Purcell JE (2009) Extension of methods for jellyfish and ctenophore trophic ecology to large-scale research. Hydrobiologia 616:23-50

Purcell JE, Arai MN (2001) Interactions of pelagic cnidarians and ctenophores with fishes: a review. Hydrobiologia 451:27-44

> Purcell JE, Decker MB (2005) Effects of climate on relative predation by scyphomedusae and ctenophores on copepods in Chesapeake Bay. Limnol Oceanogr 50:376-387

> Purcell JE, Grover JJ (1990) Predation and food limitation as causes of mortality in larval herring at a spawning ground in British Columbia. Mar Ecol Prog Ser 59:55-61

Purcell JE, Sturdevant MV (2001) Prey selection and dietary overlap among zooplanktivorous jellyfish and juvenile fishes in Prince William Sound, Alaska. Mar Ecol Prog Ser 210:67-83

Purcell JE, Cresswell FP, Cargo DG, Kennedy VS (1991) Differential ingestion and digestion of bivalve larvae by the scyphozoan Chrysaora quinquecirrha and by the ctenophore Mnemiopsis leidyi. Biol Bull (Woods Hole) 180:103-111

Purcell JE, Nemazie DA, Dorsey SE, Houde ED, Gamble JC (1994) Predation mortality of bay anchovy Anchoa mitchilli eggs and larvae due to scyphomedusae and ctenophores in Chesapeake Bay. Mar Ecol Prog Ser 114: $47-58$

Purcell JE, Uye S, Lo WT (2007) Anthropogenic causes of jellyfish blooms and direct consequences for humans: a review. Mar Ecol Prog Ser 350:153-174

Purcell JE, Clarkin E, Doyle TK (2012) Foods of Velella velella (Cnidaria: Hydrozoa) in algal rafts and its distribution in Irish seas. Hydrobiologia 690:47-55

Purcell JE, Baxter EJ, Fuentes VL (2013) Jellyfish as products and problems of aquaculture. In: Allan G, Burnell G (eds) Advances in aquaculture hatchery technology. Woodhead Publishing Series in Food Science, Technology and Nutrition No. 242. Woodhead Publishing, Cambridge, p 404-430

Purcell JE, Decker MB, Breitburg DL, Broughton KJ (2014) Fine-scale vertical distributions of Mnemiopsis leidyi ctenophores: predation on copepods relative to stratification and hypoxia. Mar Ecol Prog Ser 500:103-120

Raffaele G (2013) Jellyfish destroys thousands farmed salmon. Available at www.fis.com/fis/worldnews/ worldnews.asp? monthyear $=\&$ day $=22 \& \mathrm{id}=64287 \& \mathrm{l}=\mathrm{e} \&$ special $=\& n d b=1 \% 20$ target $=($ accessed 22 Oct 2013)

Rosa S, Pansera M, Granata A, Guglielmo L (2013) Interannual variability, growth, reproduction and feeding of Pelagia noctiluca (Cnidaria: Scyphozoa) in the Straits of Messina (Central Mediterranean Sea): linkages with temperature and diet. J Mar Syst 111-112: 97-107

Rossi S, Sabatés A, Latasa M, Reyes E (2006) Lipid biomarkers and trophic linkages between phytoplankton, zooplankton and anchovy (Engraulis encrasicolus) larvae in the NW Mediterranean. J Plankton Res 28:551-562

> Sabatés A, Zaragoza N, Grau C, Salat J (2008) Vertical distribution of early developmental stages in two coexisting clupeoid species, Sardinella aurita and Engraulis encrasicolus. Mar Ecol Prog Ser 364:169-180

> Sabatés A, Pagès F, Atienza D, Fuentes VL, Purcell JE, Gili JM (2010) Planktonic cnidarian distribution and feeding of Pelagia noctiluca from near shore to open sea in the NW Mediterranean. Hydrobiologia 645:153-165

Sullivan BK, Garcia JR, Klein-MacPhee G (1994) Prey selection by the scyphomedusan predator Aurelia aurita. Mar Biol 121:335-341

Sullivan BK, Suchman CL, Costello JH (1997) Mechanics of prey selection by ephyrae of the scyphomedusa Aurelia aurita. Mar Biol 130:213-222

Tilves U, Fuentes V, Marambio M, Canepa A, Olariaga A, Gili JM, Purcell JE (2012) Predation by the scyphozoan Pelagia noctiluca on Mnemiopsis leidyi ctenophores in the NW Mediterranean Sea. J Plankton Res 35: 218-224

Vućtić T (1982) Unusual occurrence of jellyfish Pelagia noctiluca in the Adriatic. Influence of the water masses dynamic on the distribution of the jellyfish Pelagia in the Adriatic. Acta Adriat 23:1-2 